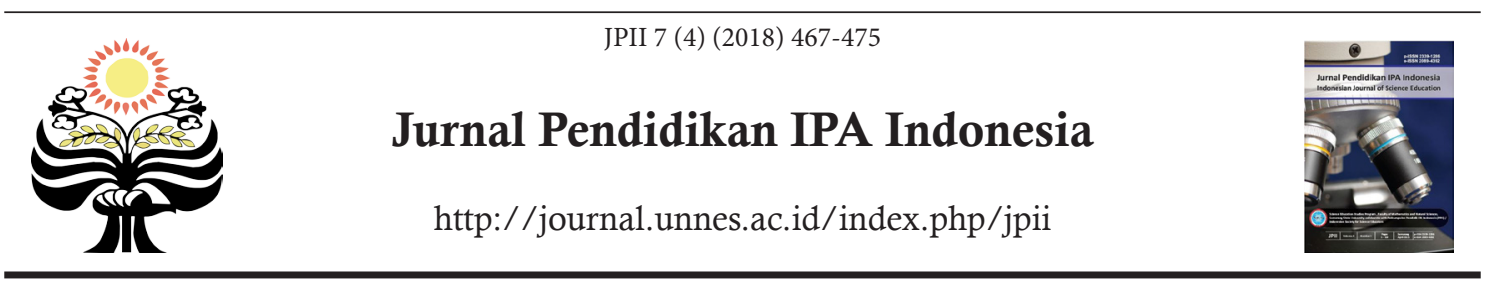

\title{
DESIGNING AN INTEGRATED CURRICULUM BASED ON LOCAL PRIMACY AND SOCIAL RECONSTRUCTION PERSPECTIVES OF WEST NUSA TENGGARA, INDONESIA
}

\author{
A. Sukri*1, M. A. Rizka ${ }^{2}$, H. G. Sakti ${ }^{3}$, K. U. Maududy ${ }^{4}$, G. Hadiprayitno ${ }^{5}$ \\ ${ }^{1}$ Biology Education, IKIP Mataran, Indonesia \\ ${ }^{2}$ Non Formal Education, IKIP Mataram, Indonesia \\ ${ }^{3}$ Educational Technology, IKIP Mataram, Indonesia \\ ${ }^{4}$ MTSN 3 Jembrana, Bali, Indonesia \\ ${ }^{5}$ Biology Education, FKIP Universitas Mataram, Indonesia
}

DOI: $10.15294 /$ jpii.v7i4.15272

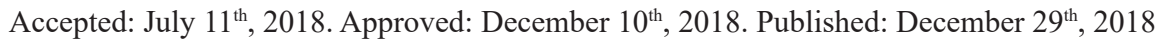

\begin{abstract}
The purpose of this study was to develop a curriculum model which included local primacy based on the principles of social reconstruction curriculum in West Nusa Tenggara. This study was a developmental research which adopted and modified Borg \& Gall developmental model (1983) with the following stages: (1) needs analysis; (2) model development; and (3) model validation. The results of needs analysis indicated that coral reef materials were the main priority of local primacy integrated into the secondary school curriculum in West Nusa Tenggara. The principles of social reconstruction curriculum were implemented in three components as the result of model design, i.e. learning objectives, learning methods (organizational learning strategies, learning delivery strategies, and learning management strategies), and learning results or assessment. The product design model was embraced in instructional tools consisting of syllabus, topic formulation and basic competence, comic learning materials, and assessment instruments. Based on the assessment qualifications on the instructional tools validation test which included three aspects, namely the content aspect, the display aspect and the accuracy aspect of language use, the mean scores were 3.4, 3.8, and 3.4 respectively. Therefore, the overall instructional tools were in a very good category.
\end{abstract}

(C) 2018 Science Education Study Program FMIPA UNNES Semarang

Keywords: curriculum design, local primacy, social reconstruction

\section{INTRODUCTION}

Indonesia is an archipelagic country with 13,466 islands with $1,922,570 \mathrm{~km} 2$ of land area and $3,257,483 \mathrm{~km} 2$ of water area (Giyanto et al., 2017). This strategic geographic position has placed Indonesia on the world's coral reef triangle. Natural treasure in the form of coral reef ecosystem is one of the advantages owned by Indonesia which must be preserved (Sukri, 2011). Based on Law No. 14 of 2011, the extent of Indonesia's co-

*Correspondence Address

E-mail: akhmadsukri@ikipmataram.ac.id ral reef area reached up to 2.5 million hectares. With this vast expanse of coral reefs, Indonesia has become one of the world's centers of coral reef diversity with almost 569 species classified into 82 genera (Giyanto et al., 2017).

One of the provinces in Indonesia with a natural treasure of reef ecosystems is the Province of West Nusa Tenggara. The beauty of the coral reef ecosystem and its coastal charm has made West Nusa Tenggara selected as the best province for tourism in the Government Award 2015 event from the Government of Indonesia. In addition, two international awards were also 
achieved by West Nusa Tenggara as World's Best Halal Honeymoon Destination and World's Best Halal Tourism Destination at the World Halal Travel Summit \& Exhibition 2015 event held in Abu Dhabi, United Arab Emirates (Winarti, 2017).

According to Subijanto (2015), local primacy is one of the potentials that exist in every region to be used as interesting contextual materials to be taught in schools. Furthermore, Marliana \& Hikmah (2013) described that local primacy integrated into education can be extracted from various potentials such as natural resources, human resources, geographic, culture, and history. In the context of this research, the local primacy is the primacy of natural resource which is a coral reef ecosystem owned by West Nusa Tenggara.

Coral reef ecosystem materials need to be introduced to the community especially to students for elementary and secondary school (Sukri et al., 2017). It is important to develop students' understanding and knowledge on coral reef ecosystem early on, so that awareness of maintaining and taking care of coral reef ecosystem especially in West Nusa Tenggara can be well-implemented (Sukri, 2011). Ironically, the materials of coral reef ecosystems in West Nusa TenggarA has not yet included in the curriculum for both primary and secondary level. Based on these findings, it is considered urgent to develop a curriculum that integrates local primacy of West Nusa Tenggara province. This is in line with the perspective of social reconstruction in an education world to accommodate local primacy, integrate the environment, solve social problems and substance of potentials around the students (Sukardi, 2016).

Social reconstruction curriculum is a curriculum design centered on problem-solving (McNeil, 1981; Stanley, 1981; Hunkins \& Ornstein, 2016), and focuses on issues faced by the society (Sulthon, 2014). The social reconstruction curriculum emphasizes cooperation and interaction, the interaction between learners and other students, the interaction between learners and teachers, the interaction between learners with their environment and other learning resources (Sulthon, 2014; Mubaroq, 2018). With this concept, coral reef ecosystem which is one of the local primaries of West Nusa TenggarA province is considered necessary to be developed into one of the lesson materials taught in elementary and middle schools in West Nusa Tenggara province.

The development of lessons that adopted local primacy in West Nusa Tenggara has been done by Sukardi (2016) who developed a creative economic-based craft and entrepreneurship model with the dimensions of the local primacy industry, namely silver and batik handicraft. There have not many types of research related to the development of curriculum that adopts local prima- cy in the form of a coral reef ecosystem in West Nusa Tenggara. An initial research done by Sukri et al. (2017) produces a learning tool that adopts the potential of coral reef ecosystem at SDN Gili Matra, West Nusa Tenggara. Furthermore, Sukri et al. (2017) also explained that the materials of coral reef ecosystem can be integrated into the subjects in elementary school for grade 4 on the theme of natural resources, and grade 6 on the theme of animal and plant conservation, as well as ecological balance.

Referring to Sukri et al. (2017), coral reef ecosystem materials need to be developed for secondary school, junior high school (SMP). Therefore, to accommodate the coral reef ecosystem materials into junior high schools, it is necessary to design an appropriate curriculum in accordance with the local primacy characteristics of West Nusa Tenggara province. The purpose of this study was to develop a curriculum model that adopt local primacy based on the principle of social reconstruction in West Nusa Tenggara. This article describes the developed curriculum design based on the principles of social reconstruction.

\section{METHODS}

This research adopted and modified the research development steps by Borg \& Gall (1983). The research implementation consisted of the following three stages: (1) needs analysis; (2) model development; and (3) model validation. Here are the descriptions of the activities undertaken in the three stages of the study.

The needs analysis adopted the fishbone diagram model (Ishikawa, 1976) to map out the school's support capacity covering aspects of people, materials, procedures, equipment, and environment in the context of curriculum development which included local primacy as the enrichment materials for junior high schools (SMP) according to the 2013 curriculum in Indonesia. The needs analysis was carried out through Focus Group Discussion (FGD) activities involving science teachers in junior high schools, principals, and curriculum development teams from the Office of Education, Youth and Sports (DISPORA) of North Lombok regency with a total of 25 people. The selection of North Lombok Regency as a research location was based on its best representation of West Nusa Tenggara with local primacy in the form of coral reef ecosystem which has been widely known by foreign countries.

The model development aimed to determine the integration model of local primacy potential into the curriculum in the form of learning tools consisting of a syllabus, lesson plans, textbooks, and assessment instruments. The model development refers to the theory of the social reconstruction curriculum (Hunkins\& Ornstein, 2016) which is actualized into three components, 
namely (a) learning objectives; (b) learning methods consisting of: strategy of organizing learning, learning delivery strategies; and learning management strategies; and (c) learning results or assessment (Gagne et al., 1992; Degeng, 2013).

Model validation intended to test the curriculum products that have been prepared through expert validation test. Model validation was performed by three experts namely, content specialists, resource display experts, and linguists. The validation test instrument was adopted from the non-text book assessment guidebook developed by the Book Center, Ministry of National Education in 2008 combined with the local resourcebased assessment instrument developed by Sukri et al. (2017). Scoring are in the range of 1-4, i.e score $1=$ less good, score 2 = good enough, score $3=$ good, and score $4=$ very good. The final qualification of textbook appraisal was as follows: 3 $<$ s $\leq 4$ (Very Good), $2<$ s $\leq 3$ (Good), $1<s \leq 2$ (Good Enough), and $s \leq 1$ (Less Good ), $s=$ score.

\section{RESULTS AND DISCUSSION}

\section{Needs Analysis Stage}

Based on need analysis, there were found some issues as follows. First, the lack of materials in junior high schools raised local primacy in West Nusa Tenggara, especially about coral reefs. The results of this FGD also found that this research activity was the first to raise the content of local primacy in the form of coral reef ecosystem as the enrichment materials for science lessons in junior high schools. Second, teachers in schools have not been provided with the necessary knowledge; therefore, they needed to be given an understanding in teaching the reef ecosystem learning materials. Third, classroom teaching activities tended to be traditional through lecturing method although some teachers have already applied several interesting teaching methods in the learning process. Therefore, the teachers had to be informed an understanding of appropriate learning methods to teach the reef ecosystem materials. Fourth, supporting equipment and infrastructure in teaching materials of the coral reef ecosystem was adequate. Fifth, the environmental aspect which is very supportive in learning the coral reef ecosystem as it exists around the students.

The need analysis results concluded that it is a necessity to raise the materials of coral reef ecosystem which is the local primacy of West Nusa Tenggara as one of the enrichment materials for a science lesson in junior high school level. These results are supported by the availability of human resources (teachers), equipment and the environment. In addition to these aspects, the integration of coral reef ecosystems into one of the subject matter of junior high schools also pays attention to socio-cultural aspects of society in as suggested by Sukri (2011).

\section{Model Development \\ FGD results with the curriculum develop- ment team and science teachers for junior high school formulated that the model could be done through insertion and adjustment of coral reef materials on Basic Competence (KD) of science especially on biology materials according to the current 2013 curriculum implemented in Indone- sia. The next step was to pack the materials of co- ral reef into a topic compiled into comic learning materials. The following in Table 1 are listed co- ral material topics, chapters of Basic Competence (KD) and a description of the materials.}

Table 1. Topic sequence, Basic Competence, and Description of the Main Materials Picturized through Comic

\begin{tabular}{lll}
\hline \multicolumn{1}{c}{ Topic } & \multicolumn{1}{c}{ Basic Competence (KD) } & \multicolumn{1}{c}{ Material Description on the Comic } \\
\hline $\begin{array}{l}\text { Topic I: } \\
\begin{array}{l}\text { Coral Reefs are Liv- } \\
\text { ing Thins }\end{array}\end{array}$ & $\begin{array}{l}\text { Referring to KD 3.2 } \\
\text { Classifying living things and objects } \\
\text { based on observed characteristics }\end{array}$ & $\begin{array}{l}\text { The iconic figure describes the characteris- } \\
\text { tics of coral reefs from physical features, as } \\
\text { well as physiological and cellular features } \\
\text { based on miscropcopic observations. }\end{array}$ \\
$\begin{array}{ll}\text { Topic II: } \\
\begin{array}{l}\text { Coral Reef Diversity } \\
\text { and Classification }\end{array}\end{array}$ & $\begin{array}{l}\text { Referring to KD 3.2 } \\
\text { Classifying living things and objects } \\
\text { based on observed characteristics }\end{array}$ & $\begin{array}{l}\text { The iconic figure explains the phylum } \\
\text { classification of living things, one of which } \\
\text { is coral reef based on cellular observations } \\
\text { (organelles), living habitats, and other } \\
\text { characteristics. }\end{array}$
\end{tabular}

Topic III:

Cellular System and

Coral Reef Body

Structure
Referring to KD 3.6

Identifying organizational systems of life from the cellular level to the organisms and major compositions of cell constituents.
The iconic figure explains the cellular system and body structure of coral reefs. 


\begin{tabular}{|c|c|c|}
\hline $\begin{array}{l}\text { Topic IV: } \\
\text { Inheritance of Na- } \\
\text { ture on Coral Reefs }\end{array}$ & $\begin{array}{l}\text { Referring to KD } 3.3 \\
\text { Applying the concept of inheritance of } \\
\text { nature in the breeding and survival of } \\
\text { living things }\end{array}$ & $\begin{array}{l}\text { The iconic figure invites students to analyze } \\
\text { various opportunities of traits derived from } \\
\text { the reproductive processes undertaken by } \\
\text { coral reefs according to Mendel's trait inheri- } \\
\text { tance laws. }\end{array}$ \\
\hline $\begin{array}{l}\text { Topic V: } \\
\text { Survival and Con- } \\
\text { servation of Coral } \\
\text { Reefs }\end{array}$ & $\begin{array}{l}\text { Referring to KD } 3.8 \\
\text { Analyzing the occurrence } \\
\text { environmental pollution and } \\
\text { its impact on the ecosystem } \\
\text { Referring to KD } 3.9 \\
\text { Analyze } \\
\text { climate change } \\
\text { and its impact } \\
\text { on the ecosystem }\end{array}$ & $\begin{array}{l}\text { The iconic figure explains the causes of } \\
\text { damage to coral reef ecosystems caused by } \\
\text { environmental pollution and global climate } \\
\text { change. The iconic figure then invites stu- } \\
\text { dents to analyze the importance of coral reefs } \\
\text { and efforts of coral reefs conservation in In- } \\
\text { donesia }\end{array}$ \\
\hline $\begin{array}{l}\text { Topic VI: } \\
\text { Coral Reef Biotech- } \\
\text { nology }\end{array}$ & $\begin{array}{l}\text { Referring to KD } 3.7 \\
\text { Understanding the concept of biotech- } \\
\text { nology and its role in human life }\end{array}$ & $\begin{array}{l}\text { The iconic figure invites students to ana- } \\
\text { lyze the use of biotechnology principles in } \\
\text { tackling various human activities (pollution) } \\
\text { that can potentially cause extinction on coral } \\
\text { reefs. One of them is environmental biotech- } \\
\text { nology (waste-eating bacteria) }\end{array}$ \\
\hline
\end{tabular}

The design of the integrated curriculum model of local primacy implemented into learning tools includes syllabus, lesson plan, comic learning materials, and assessment packed into three learning variable components adopted from Reigeluth \& Merrill (1978), consisting of (a) learning conditions, (b) learning methods, and (c) learning outcomes. Each component of the learning variable refers to the social reconstruction theory that is considered relevant to the developed model. This is in accordance with the principle of social reconstruction theory because it places an integrated education with the environment, solves social problems, and learns content excavated from environmental potentials around students (Sukardi, 2016).

Learning conditions are factors which influence the effect of using certain methods to improve learning outcomes (Gagne et al, 1992; Degeng, 2013). Furthermore, Degeng (2013) classified the learning conditions into four variables namely learning objectives, characteristics of the subject, constraints, and characteristics of students. The learning conditions in this study focused on two classifications, namely learning objectives and characteristics of the subject. The structure of learning objectives in this development model referred to the structure of the 2013 curriculum which consists of (a) the learning objectives, (b) the core competence, and (c) basic competence. The objectives of the subject study pointed to the principle of constructivism and social reconstruction to build students' understanding of the coral reef biological system from the simplest aspect to the most complex aspects suitable with conceptual orientation objective (Degeng, 2013). The determination of core competence $(\mathrm{KI})$ and basic competence $(\mathrm{KD})$ adopted and modified in the science syllabus for junior high school according to the 2013 curriculum is shown in Table 1.

The learning method covered three components, namely (a) organizing learning strategy, (b) learning delivery strategy, and (c) learning management strategy. The strategy of organizing learning in the developed model points to the content organization by involving more than one concept, procedure, or principle with the aim to unite the entire contents of the field study (Degeng, 2013; Reigeluth \& Merrill, 1978). The learning organization included: (1) arranging coral reef materials into 7 chapters (Table 1); (2) presenting the core and basic competence for each chapter; (3) determining the storyline according to the supporting materials and images, and (d) the task or exercise displayed at the end of each topic. The sequences of coral reefs comic materials in sequence starting from the simplest to the most complex materials.

The learning delivery strategy on the developed model highlighted the principles of social reconstruction which emphasizes the existence of collaboration, interaction, communication and direct practice (Sukardi, 2017). Therefore, the learning delivery strategy was actualized in the form of group learning, face-to-face activities in the classroom, field trips to see the real conditions of coral reef ecosystems in the real environment. 
The delivery strategy pointed to the principle of social reconstruction by implementing social reconstruction learning method adopted from Luisa (2007) combined with social reconstruction syntax developed by Sukardi (2017). Learning activities were implemented through several activities: (1) forming heterogeneous learning groups in terms of gender, abilities, and cultures. The formation of heterogeneous groups is expected to establish interaction and cooperation among students (Pitriani et al, 2013); (2) initial knowledge activation; (3) presentation of new knowledge; (4) conducting exercises through problem analysis; (5) conducting research through field trip activities; (6) drawing conclusions; and (7) reflections on the learning process.

Learning outcomes are all impacts serve as a reference for using a method under different conditions (Degeng, 2013). The expected lear- ning outcomes were assessments oriented to the principle of social reconstruction and problemsolving for real problems in a student's life (Hunkins\& Ornstein, 2016). The assessment activities include: (a) guidance of field trip activity combined with project-based assessment including planning, data collection, organizing, process, analysis and concluding, and displaying data (Fauziah \& Saputro, 2018); and (b) critical analysis reports as the results of field monitoring of coral reef problems.

\section{Product Validation Test Results}

The product validation test was done to assess product appearance and language whether it is good and correct according to Indonesia standard rules. The results of the curriculum product validation test are shown in Table 2-4.

Table 2. The Content Validation Results

\begin{tabular}{llc}
\hline No & \multicolumn{1}{c}{ Scoring Components } & Evaluation Score \\
\hline 1 & $\begin{array}{l}\text { The correlation between basic competence and materials elaboration } \\
2\end{array}$ & 3 \\
3 & $\begin{array}{l}\text { The harmony between basic competence and materials elaboration } \\
\text { chapter or topic }\end{array}$ & 4 \\
4 & Learning syntax according to the basic competence and main materials & 3 \\
5 & $\begin{array}{l}\text { The validity of the substance according to scientific principles } \\
6\end{array} \quad \begin{array}{l}\text { The explanation of coral reef materials according to the improvement of stu- } \\
\text { dents' cognitive. }\end{array}$ & 3 \\
7 & $\begin{array}{l}\text { The harmony of comic illustration with the materials in every topic or chapter } \\
8\end{array}$ & 4 \\
Overall rate & 3 \\
\hline $\begin{array}{l}\text { Note: } \\
\text { scoring qualification }\end{array}$ & $3,4 *$ \\
$3<S \leq 4$ (very good), $2<S \leq 3$ (good), $1<S \leq 2$ (good enough), $S \leq 1$ (less good), $S=$ score
\end{tabular}

Table 3. The Appearance Validation Results

\begin{tabular}{llc}
\hline No & \multicolumn{1}{c}{ Scoring Components } & Evaluation Score \\
\hline A & $\begin{array}{l}\text { Design of the Topic, Basic Competence, and Syllabus } \\
\end{array}$ & $\begin{array}{l}\text { The design of the topic displaying the coral reef materials comprehen- } \\
\text { sively }\end{array}$ \\
2 & Clarity of the chapter design & 4 \\
3 & Clarity of the basic competence design & 4 \\
4 & Clarity of the main material elaboration & 4 \\
5 & Clarity of the learning syntax in the lesson plans & 3 \\
6 & $\begin{array}{l}\text { Clarity of the syllabus description ( learning source, time allocation, } \\
\text { learning methods, and evaluation) }\end{array}$ & 4 \\
\hline
\end{tabular}




\begin{tabular}{lll}
\hline B & Comic Learning Materials & \\
7 & Clarity of the illustrations in every topic or chapter & 3 \\
8 & The coherence of displayed coral reef materials & 4 \\
9 & Clarity of the comic storyline & 4 \\
10 & Clarity of the information displayed in the comic & 4 \\
11 & The use of proportional color gradation & 4 \\
12 & Harmony between pictures, font size, and types used in the comic & 4 \\
Overall rate & $3,8^{*}$ \\
\hline
\end{tabular}

* scoring qualification

$3<S \leq 4$ (very good), $2<S \leq 3$ (good), $1<S \leq 2$ (quite good), $S \leq 1$ (less good), $S=$ score

Based on the content validation results, the eight components' average score was 3.4. As a result, the curriculum products consisting of a syllabus and comic teaching materials were in a very good category. Table 2 shows that three of the eight assessment aspects were in the very good category with a score of 4 . All the three assessment aspects included the 2, 6, and 7 assessment related to the suitability of coral reef ecosystems with basic competence, student cognitive levels, and illustrations shown in comics for each topic. This indicated that the coral reef ecosystem materials have been described in the curriculum well. Similar results were obtained by Hartini et al. (2018) which showed that teaching materials integrated with local wisdom had been prepared in accordance with aspects of content validation and appearance.
The appearance validation test results presented in Table 3 showed that the average score was 3.8 and belonged to the very good category. These results indicated that in terms of appearance, the developed curriculum products have met the criteria for all assessment components. Based on Table 3, it is known that out of the 12 components, there are 2 components scored 3, namely the assessment components 5 and 7 . This elucidated that overall; the validation test results achieved a high validity score. According to Afriadi et al. (2013), the magnitude of the validity score plays an important role in drawing conclusions. Therefore, the higher the validity, the better the conclusions are drawn (Hartini et al., 2018). The high validation test results are also shown in Table 4 with an average score of 3.4. Thus, the language used was in a very good category.

Table 4. The Language Validation Results

\begin{tabular}{llc}
\hline No & \multicolumn{1}{c}{ Scoring Components } & Evaluation Score \\
\hline 1 & Standardized words and sentence & 4 \\
2 & The accuracy of idiomatic expressions & 3 \\
3 & Standardized sentence arrangement & 3 \\
4 & A clear correlation between information and sentences & 4 \\
5 & Punctuation accuracy & 3 \\
\multicolumn{2}{l}{ Overall rate } & $3,4^{*}$ \\
\hline
\end{tabular}

*scoring qualification

$3<S \leq 4$ (very good), $2<S \leq 3$ (good), $1<S \leq 2$ (quite god), $S \leq 1$ (less good), $S=$ score

The main purpose of the social reconstruction curriculum is to include students in solving social problems (McNeil, 1981; Stanley, 1981; Hunkins\& Ornstein, 2016; Sulthon, 2014). The social reconstruction curriculum emphasizes interaction and substance extracted from the surrounding potentials (White, 2001; Sukardi, 2016; Sulthon, 2014; Mubaroq, 2018). The basic concept of social reconstruction theory is the foundation for the development of science curriculum integrated with local primacy of West Nusa Tenggara, Indonesia. The concept of social reconstruction theory in this research was implemented through the learning materials and learning condition, and assessment activities which held firmly the local wisdom (McNeil, 1981; Stanley, 1981; Hunkins\& Ornstein, 2016; Pitriani et al., 2013).

One implication of the social reconstruction theory in this study was implemented in the content or subject matter that is adopted from the 
local a.k.a the coral reef ecosystem. According to Suyitno et al. (2015), local wisdom in the school environment needs to be introduced and taught to students in order to produce graduates who are relevant to the needs. In addition, Anggraini (2017) revealed that learning based on local wisdom can enrich the knowledge and character development of the students. Subali et al. (2015) reported that the implementation of teaching design based on local wisdom influenced the character of students as proven by the emergence of 11 positive characters on student performance such as caring toward the environment. The research results of Sugiyo \& Purwastuti (2017) showed that the potential of local wisdom in the community can be used as a character education model for elementary school students. The results are in line with Mayne's (2014) opinion that the social reconstruction approach needs to be integrated into teacher training programs as a key component in improving the quality of education.

The implications of the social reconstruction theory in the developed design were also reflected in the learning activities undertaken. Learning activities prioritize the interaction among learners which is the principle of social reconstruction theory (Sulthon, 2014; Mubaroq, 2018). This concrete form of interaction activity is reflected in the learning group activities implemented through the social reconstruction learning model (Luisa, 2007; Sukardi, 2017). The heterogeneous learning group consists of students with different gender and academic ability. Group learning is expected to establish interaction between learners, learners with teachers, and learners with learning environment. The results of previous studies have shown that social interaction influences student learning outcomes and motivation (Fitriastuti, 2013, Hurst et al., 2013; Sari et al, 2013; Mulyaningsih, 2014; Nismawati, 2015; Rahmah, 2016; Murti \& Heryanto, 2016). Aside from being positively affects student achievement social interaction is also plays an important role in improving the quality of learning (Jung et al., 2002; Essam \& A1-Ammary, 2013). The results of this design are in line with Barakett \& Freedman (2001) research suggesting that learning based on the principle of social reconstruction is done to achieve high-level thinking skills through participatory, dialogical, and interactive learning.

Interaction activities are not only carried out in the classroom, but also carried out through field activities. This refers to the principle of social reconstruction theory that the substance or subject matter is extracted from the potential that exists around the student (White, 2001). Furthermore, Sukardi (2016) emphasized that the setting of activities outside the classroom is intended to provide opportunities for students to acquire knowledge and skills through involvement in the real world. The results of various studies show that field trip activities can improve students' academic performance (Amosa et al., 2015), creative and practical thinking (Mahgoub \& Alawad, 2014), conceptual understanding (Taneo, 2017), learning experience (Higgins et al., 2012; Nyumba et al., 2018), learning outcomes (Patrick, 2010), knowledge and attitudes toward multicultural (Prokop et al, 2007; Olukayode \& Tina, 2013; Neiman \& Ades, 2014); and student academic achievement (Estawul et al., 2015).

The third implication of the principle of social reconstruction contained in this design was in the form of assessment. The developed assessments were problem-oriented (Hunkins\& Ornstein, 2016) based on the potential around students. This form of assessment was a projectbased assessment which outlined in the critical analysis report on the results of the on-field reef problem. Project-based assessment is one of the authentic assessment models (Fauziah \& Saputro, 2018). According to Tai \& Yuen (2007), authentic assessment obtained positive results to improve problem-solving skills, teamwork, and increased student knowledge. The results of this design are in accordance with Fook \& Sidhu's (2010) suggestions that authentic assessment is more acceptable to students and serves as an alternative to standardized judgments.

Overall, the curriculum design that adopts local primacy generated in this study has been in accordance with the principle of social reconstruction used as a reference in the development of the model. In addition, the results of this study are complementary to previous similar studies in developing local primacy, especially coral reef ecosystems integrated into lessons for secondary school levels.

\section{CONCLUSION}

The research results revealed that the integration of coral reef materials can be done through the insertion and adjustment of the main coral reef materials in the Basic Competencies (KD) of science subjects especially in biological materials for junior high school level. The results of this study also indicated that curriculum development adopting local primacy was appropriate based on 
the principle of social reconstruction as the materials originated from or was explored from the potentials existing around the students.

The resulting curriculum design and products can be used as a blueprint for other areas in curriculum development which raise the potential of the region as the enrichment materials for primary and secondary schools in Indonesia.

\section{ACKNOWLEDGEMENTS}

The author expresses his gratitude to the Directorate of Research and Community Service (DRPM) of the Ministry of Research, Technology and Higher Education of the Republic of Indonesia who has funded this research through the National Strategic Research Institution (PSNI) Scheme for the year of 2018 .

\section{REFERENCES}

Afriadi, R., Lufri, L., \& Razak, A. (2013). Pengembangan Modul Biologi Bermuatan Pendidikan Karakter Pada Materi Sistem Reproduksi Manusia Kelas XI SMA, Kolaboratif, 1(2), 19-30.

Amosa, A. G. A., Ogunlade, O. O., \& Atobatele, A. S. (2015). Effect of Field Trip on Students' Academic Performance in Basic Technology in Ilorin Metropolis, Nigeria. Malaysian Online Journal of Educational Technology, 3(2), 1-6.

Anggraini, P., \& Kusniarti, T. (2017). Character and Local Wisdom-Based Instructional Model of Bahasa Indonesia in Vocational High Schools. Journal of Education and Practice, 8(5), 23-29.

Barakett, J., Saccá, E. J., \& Freedman, J. (2001). Social Reconstruction through Video Art: a Case Study. Transformations: The Journal of Inclusive Scholarship and Pedagogy, 12(1), 93-107.

Borg, W. R., \& Gall, M. D. (1983). Educational research an introduction. New York and London.

Degeng, I.N.S. (2013). Ilmu Pembelajaran: Klasifikasi Variabel untuk Pengembangan.

Essam, S., \& Al-Ammary, J. (2013). The Impact of Motivation and Social Interaction on the ELearning at Arab Open University, Kingdom of Bahrain. Creative Education, 4(10), 21-28.

Estawul, S. S., Sababa, L. K., \& Filgona, J. (2016). Effect of Fieldtrip Strategy on Senior Secondary School Students'academic Achievement in Geography in Numan Educational Zone, Adamawa State, Nigeria. European Journal of Education Studies, 2(12), 138-154.

Fauziah, D., \& Saputro, D. R. S. (2018, March). Mathematics Authentic Assessment on Statistics Learning: The Case for Student Mini Projects. In Journal of Physics: Conference Series (Vol. 983, No. 1, p. 012123). IOP Publishing.

Fitriastuti, F. (2013). Pengaruh Interaksi Sosial dalam Keluarga dan Minat Belajar Siswa terhadap Prestasi Belajar Siswa. OIKONOMIA-Jurnal
Pendidikan Ekonomi, 2(3), 183-188.

Fook, C. Y., \& Sidhu, G. K. (2010). Authentic assessment and Pedagogical Strategies in Higher Education. Journal of Social Sciences, 6(2), 153-161.

Gagne, R.M., Briggs, L.J.,\& Wager, W.W. (1992). Principles of Instructional Design. (Fourth Edition). USA: Harcourt Brace College Publishers.

Giyanto., Abrar, M., Hadi, T.A., Budiyanto, A., Hafizt, M., Salatalohy, A., \& Iswari, M.Y. (2017). Status Terumbu Karang Indonesia 2017.

Hartini, S., Firdausi, S., Misbah., \& Sulaeman, N.F. (2018). The Development of Physics Teaching Materials Based on Local Wisdom to Train Saraba Kawa Character, JPII, 7(2), 130-137.

Higgins, N., Dewhurst, E., \& Watkins, L. (2012). Field trips as Short-Term Experiential Learning Activities in Legal Education. The Law Teacher, 46(2), 165-178.

Hunkins, F. P., \& Ornstein, A. C. (2016). Curriculum: Foundations, Principles, and Issues. Pearson Education.

Hurst, B., Wallace, R., \& Nixon, S. B. (2013). The Impact of Social Interaction on Student Learning. Reading Horizons, 52(4), 375-398.

Ishikawa, K. (1976). Guide to Quality Control: Industrial Engineering and Technology. Tokyo, Japan: Asian Productivity Organization.

Jung, I., Choi, S., Lim, C., \& Leem, J. (2002). Effects of Different Types of Interaction on Learning Achievement, Satisfaction and Participation in Web-Based Instruction. Innovations in education and teaching international, 39(2), 153-162.

Luisa. (2007). Model for Research on Multiculturality in Mathematics Education. Spain: University of Granada.

Mahgoub, Y., \& Alawad, A. (2014). The Impact of Field Trips on Students' Creative Thinking and Practices in Arts Education. Journal of American Science, 10(1), 46-50.

Marliana, M., \& Hikmah, N. (2013). Pendidikan Berbasis Muatan Lokal Sebagai Sub Komponen Kurikulum. Dinamika Ilmu, 13(1), 105-119.

McNeil, J.D. (1981). Curriculum a Comprehensive Introduction (Second Edition). Boston: Litle Brown and Company.

Mayne, H. (2014). The Social Reconstructionist Approach to Teacher Education: a necessary component to achieving excellence and quality education for all. Research in Comparative and International Education, 9(1), 48-55.

Mubaroq, S. (2018). Konsep Kurikulum Rekonstruksi Sosial dalam Menghadapi Pembelajaran di Era Modern. Belajar Bahasa, 3(1), 93-102.

Mulyaningsih, I. E. (2014). Pengaruh Interaksi Sosial Keluarga, Motivasi Belajar, dan Kemandirian Belajar Terhadap Prestasi Belajar. Jurnal Pendidikan dan Kebudayaan, 20(4), 441-451.

Murti, S., \& Heryanto, H. (2016). Pengaruh Kualitas Interaksi Sosial di Lingkungan Keluarga Terhadap Prestasi Belajar Siswa (Studi Kasus di SMA Negeri 5 Samarinda). Al Ibtida: Jurnal Pendidikan Guru MI, 3(2), 253-268. 
Neiman, Z., \& Ades, C. (2014). Contact with Nature: Effects of Field Trips on Pro-Environmental Knowledge, Intentions And Attitudes. Ciência \& Educação (Bauru), 20(4), 889-902.

Nismawati, N. (2015). Pengaruh Syarat Interaksi Sosial Guru terhadap Motivasi Belajar Sosiologi Siswa di SMA Negeri 1 Mallusetasi Kabupaten Barru, Jurnal Sosialisasi, 2(2), 86-90.

O Nyumba, T., Wilson, K., Derrick, C. J., \& Mukherjee, N. (2018). The Use of Focus Group Discussion Methodology: Insights from Two Decades of Application in Conservation. Methods in Ecology and Evolution, 9(1), 20-32.

Olukayode, A. S., \& Tina, S. E. (2013). Effects of cooperative Learning and Field Trip Strategies on Secondary School Students' Knowledge of and Attitudes to Multicultural Concepts in Social Studies. Group, 4(22), 35-42.

Patrick, A. O. (2010). Effects of Field Studies on Learning Outcome in Biology. Journal of Human Ecology, 31(3), 171-177.

Pitriani, N.L., Sujana, I.W., \& Putra, I.K.A. (2013). Pengaruh Model Pembelajaran Rekonstruksi Sosial terhadap Hasil Belajar IPS Siswa Kelas IV SDN Gugus VII Yos Sudarso Sanur Denpasar. Mimbar PGSD Undiksha, 1(1), 1-9.

Prokop, P., Tuncer, G., \& Kvasničák, R. (2007). Shortterm Effects of Field Programme on Students' Knowledge And Attitude Toward Biology: A Slovak Experience. Journal of Science Education and Technology, 16(3), 247-255.

Rahmah, J. (2016). Pengaruh Interaksi Sosial Siswa Terhadap Prestasi Belajar PAI di Madrasah. EDUCASIA, 1(1), 19-30.

Reigeluth, C. M., \& Merrill, M. D. (1978). A Knowledge Base for Improving our Methods of Instruction. Educational Psychologist, 13(1), 57-70.

Sari, N.M.L.A., Parmiti, D.P., \& Murda, I.N. (2013). Pengaruh Model Pembelajaran Interaksi Sosial Terhadap Hasil Belajar IPS Siswa Kelas IV di SD Gugus 1 Kecamatan Tabanan. Mimbar PGSD Undiksha, 1(1), 1-10.

Subali, B., Sopyan, A., \& Ellianawati, E. (2015). Developing Local Wisdom Based Science Learning Design to Establish Positive Character in Elementary School. Jurnal Pendidikan Fisika Indonesia, 11(1), 1-7.

Subijanto, S. (2015). The Policy of Educational Program Based on Local Content in State Senior High School 2 Pekalongan. Jurnal Pendidikan dan Kebudayaan, 21(2), 115-134.
Sugiyo, R., \& Purwastuti, L. A. (2017). Local WisdomBased Character Education Model in Elementary School in Bantul Yogyakarta Indonesia. Sino-US English Teaching, 14(5), 299-308.

Stanley, W. B. (1981). Toward a Reconstruction of Social Education. Theory \& Research in Social Education, 9(1), 67-89.

Sukardi, S. (2016). Desain Model Prakarya dan Kewirausahaan Berbasis Ekonomi Kreatif Berdimensi Industri Keunggulan Lokal. Cakrawala Pendidikan, XXXV(1), 114-124.

Sukardi, S. (2017). Efektifitas Model Prakarya Dan Kewirausahaan Berbasis Ekonomi Kreatif Berdimensi Industri Keunggulan Lokal Terhadap Keinovatifan Siswa. Cakrawala Pendidikan, $X X X V I(2), 267-279$.

Sukri, A. (2011). Pelestarian Ekosistem Terumbu Karang Gili Matra Melalui Pendidikan Lokal Berbasis Lingkungan. Jurnal Pendidikan Biologi, 3(1), 19-27.

Sukri, A., Harisanti, B. M., Wahyuni, B. S., Suharti, S., \& Amirudin, A. (2017). Uji Validasi Bahan Ajar Berbasis Keunggulan Lokal di SDN Gili Matra, Lombok Utara Nusa Tenggara Barat. Jurnal Edukasi Matematika dan Sains, 5(2), 9297.

Sulthon, S. (2014). Dinamika Pengembangan KuriKulum Ditinjau Dari Dimensi Politisasi PenDiDikan Dan eKonomi. Edukasia: Jurnal Penelitian Pendidikan Islam, 9(1), 43-72.

Suyitno, I., Kamal, M., Sunoto., \& Suherjanto, I. (2015). Pemanfaatan Potensi Kearifan Lokal Dalam Pembelajaran dengan Teknik Observasi Lingkungan di Sekolah Dasar, Prosiding Seminar Nasional Pengembangan Karir Pendidik Berbasis Karya Ilmiah, Universitas Negeri Malang: Agustus.

Tai, G. X. L., \& Yuen, M. C. (2007). Authentic Assessment Strategies in Problem Based Learning. In Proceedings of ASCILITE.

Taneo, M. (2017). Effect of Field Trip Learning Method toward the Conceptual Understanding of Local History. Journal of Research \& Method in Education, 7(5), 40-44.

White, S. R. (2001). Reconstructionism and Interdisciplinary Global Education: Curricula Construction in a Teilhardian Context. International Education-Knoxville-, 31(1), 5-23.

Winarti, O. (2017). Halal Tourism in Indonesia: Does it attract only Muslim Tourists?. Jurnal Studi Komunikasi, 1(3), 232-239. 